\title{
Building Science-Based Groundwater Tools and Capacity in Armenia for the Ararat Basin
}

\author{
By Janet M. Carter' ${ }^{1}$, Joshua F. Valder', Mark T. Anderson'1, Patrick Meyer², and Jo L. Eimers'
}

\section{Introduction}

The U.S. Geological Survey (USGS) and U.S. Agency for International Development (USAID) began a study in 2016 to help build science-based groundwater tools and capacity for the Ararat Basin in Armenia. The growth of aquaculture and other uses in the Ararat Basin has been accompanied by increased withdrawals of groundwater, which has resulted in a reduction of artesian conditions (decreased springflow, well discharges, and water levels) including loss of flowing wells in many places (Armenia Branch of Mendez England and Associates, 2014; Yu and others, 2015). This study is in partnership with USAID/Armenia in the implementation of its Science, Technology, Innovation, and Partnerships (STIP) effort through the Advanced Science and Partnerships for Integrated Resource Development (ASPIRED) program and associated partners, including the Government of Armenia, Armenia's Hydrogeological Monitoring Center, and the USAID Global Development Lab and its GeoCenter. Scientific tools will be developed through this study that groundwater-resource managers, such as those in the Ministry of Nature Protection, in Armenia can use to understand and predict the consequences of their resource management decisions.

\section{Background and Problem}

The Ararat Basin is located to the south of the capital city of Yerevan along the border between Armenia and Turkey (fig. 1). The Ararat Basin is the most arid region of Armenia with annual precipitation of about 10 inches (Nalbandyan, 2012). Despite the arid climate, this region contains the largest agricultural and fish farming zone in Armenia (Yu and others, 2015) enabled by high-quality water from wells drilled into the artesian aquifer that underlies the Ararat Basin. The water is suitable for human consumption without additional treatment (Yu and others, 2015). The artesian aquifer is contained in Quaternary deposits of lava, primarily porous and fractured basalts, and 80 percent of springs in the Ararat Basin originate from these lava deposits (Nalbandyan, 2012). Recharge to the artesian aquifer is through direct infiltration of precipitation and loss of flow in surface streams, especially in upland areas.

'U.S. Geological Survey.

${ }^{2}$ U.S. Agency for International Development.

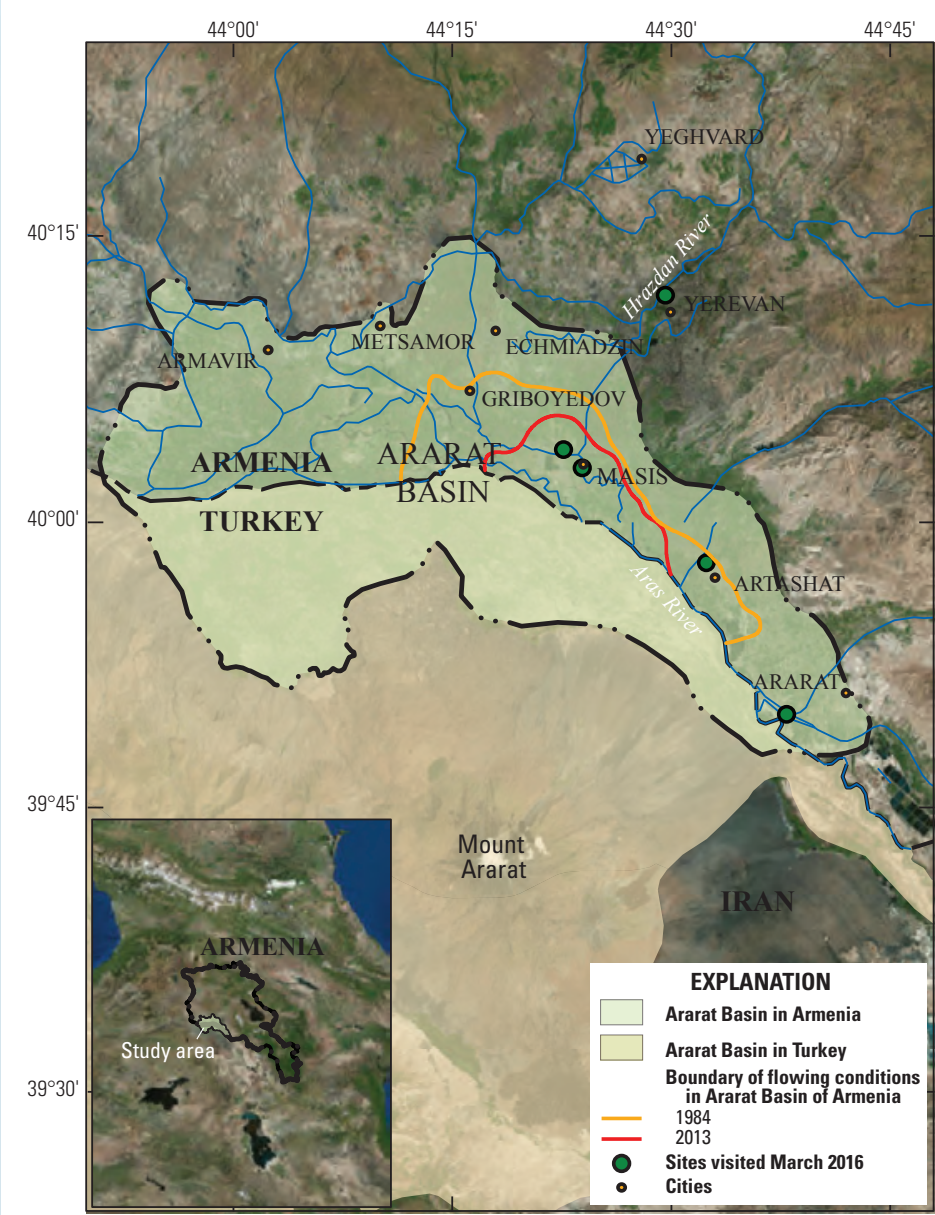

Service Layer Credits: Source: Esri, DigitalGlobe, GeoEye, Earthstar Geographics, CNES/Airbus DS, USDA, USGS, AEX, Getmapping, Aerogrid, IGN, IGP, swisstopo, and the GIS User Community

Figure 1. Location of Ararat Basin (study area) and changes in flowing conditions of the artesian aquifer in Armenia. (Modified from Armenian Branch of Mendez England and Associates, 2014.)

Withdrawals of groundwater in the Ararat Basin have increased since about 2000 with the growth of aquaculture to raise trout, sturgeon, and other cold-water fish (fig. 2). Although the aquaculture demand is relatively recent, the artesian aquifer also supplies water for municipal, irrigation, energy, and industrial uses in the Ararat Basin. As a result of increased groundwater withdrawals, many wells in the basin have ceased to flow and 


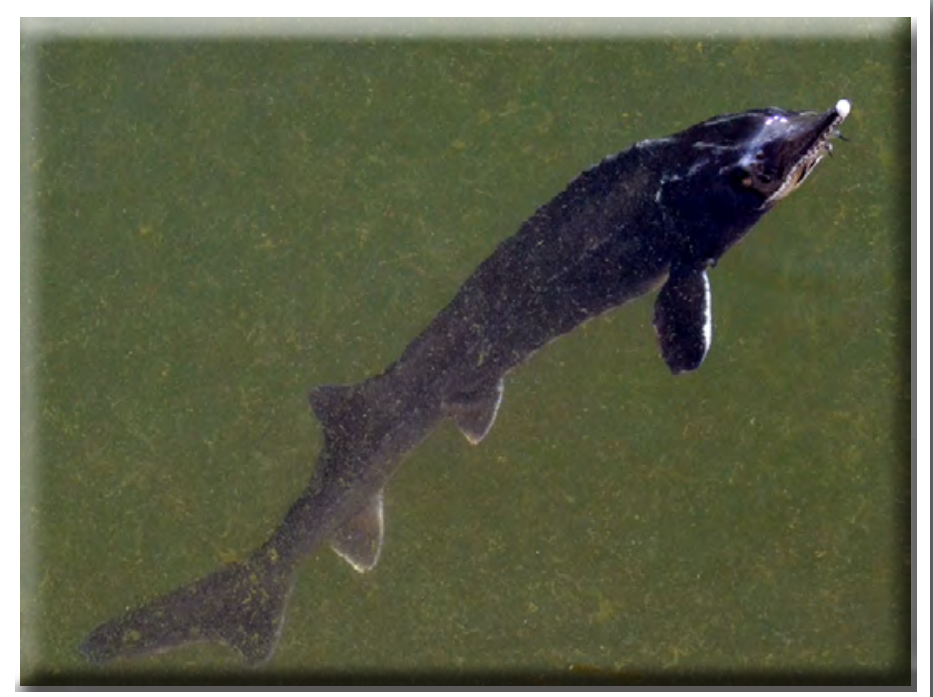

others have diminished flow (fig. 1; Armenia Branch of Mendez England and Associates, 2014). As the area of flowing conditions has reduced in the Ararat Basin, the wells supplying drinking and irrigation water to 31 communities have ceased flowing, and the Armenian Nuclear Power Plant at Metsamor (fig. 1) is no longer able to meet water requirements from spring discharges (Yu and others, 2015). Numerous abandoned wells exist in the area, with some continuing to discharge water on the land surface (fig. 3), creating environmental hazards and continued depletion of the artesian aquifer. Streamflows and lake levels also have diminished as a result of aquifer depletion (fig. 4; Armenia Branch of Mendez England and Associates, 2014).

\section{Objectives}

The objectives for this study are to (1) characterize the hydrogeologic framework and conditions in the Ararat Basin; (2) summarize groundwater resources in the Ararat Basin and provide technical assistance to design a groundwater monitoring network; (3) and provide technical workshop(s) to build expertise in country to understand and manage groundwater resources. Characterization of the hydrologic framework will be through existing geologic maps, remote sensing imagery, well records and logs, and groundwater-level measurements collected in the Ararat Basin by in-country partners. Critical data gaps based on the hydrologic framework will be identified to assist in developing key components of a groundwater monitoring network. In-country hydrology professionals, the USGS, and USAID will outline a plan for sustainable groundwater use in the Ararat Basin.

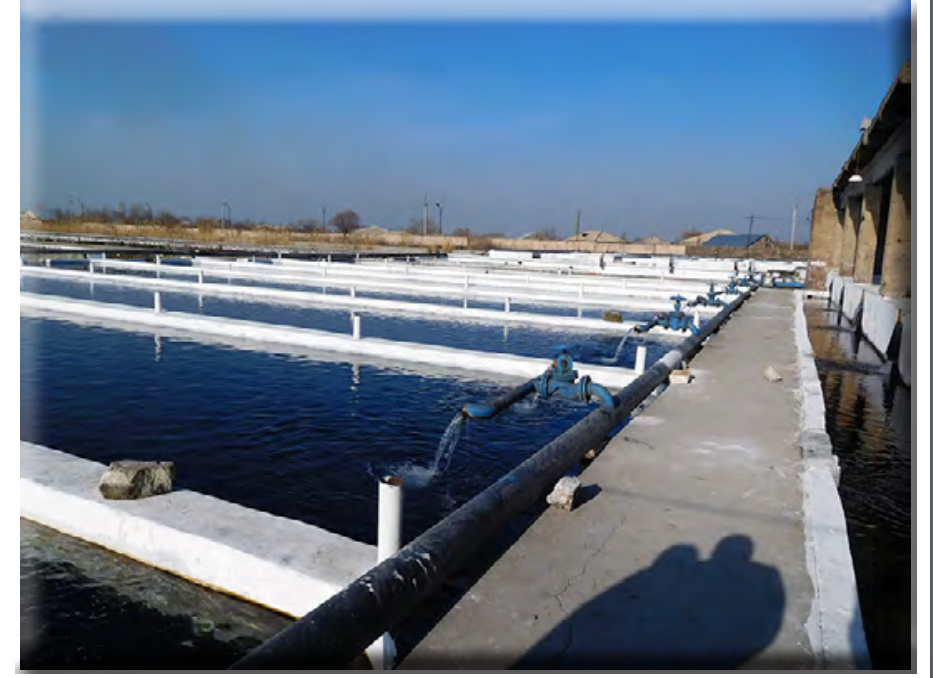

Figure 2. Sturgeon (top), trout (middle), and other cold-water fish are raised at fish farms (bottom) using groundwater withdrawals from an artesian aquifer in the Ararat Basin. The trout shown in the middle photograph is called a "golden trout" in Armenia and is a color variant of the Rainbow Trout.

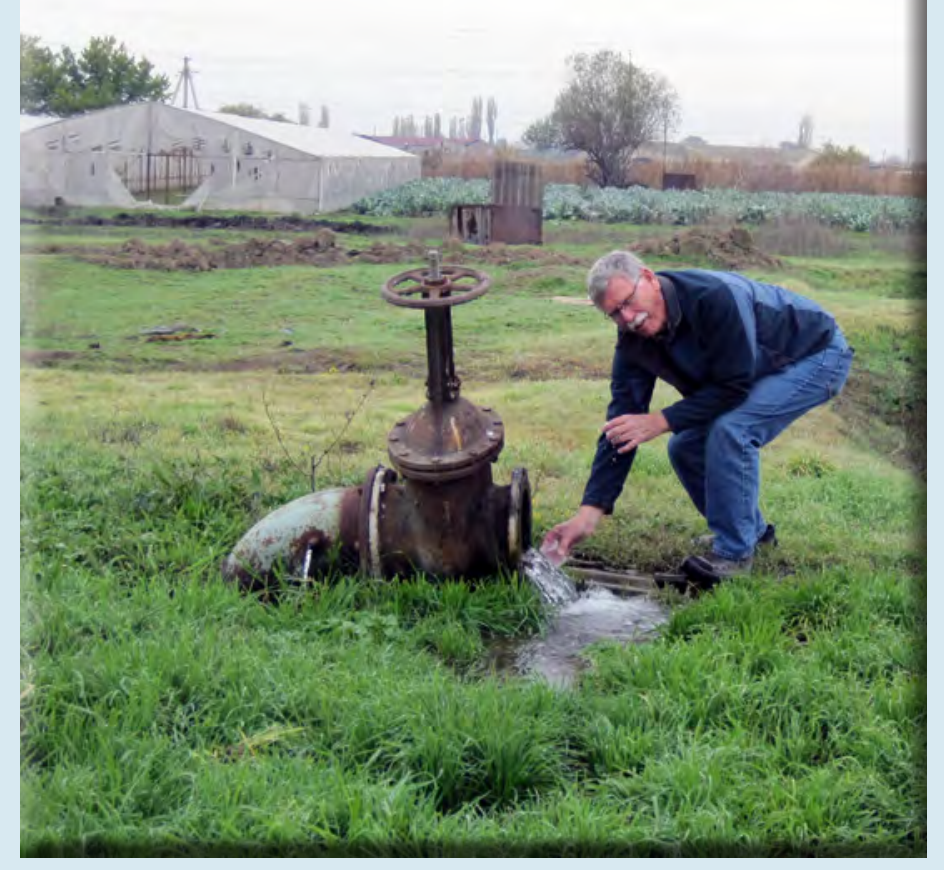

Figure 3. An abandoned well in the Ararat Basin flowing water to the land surface in November 2015. 


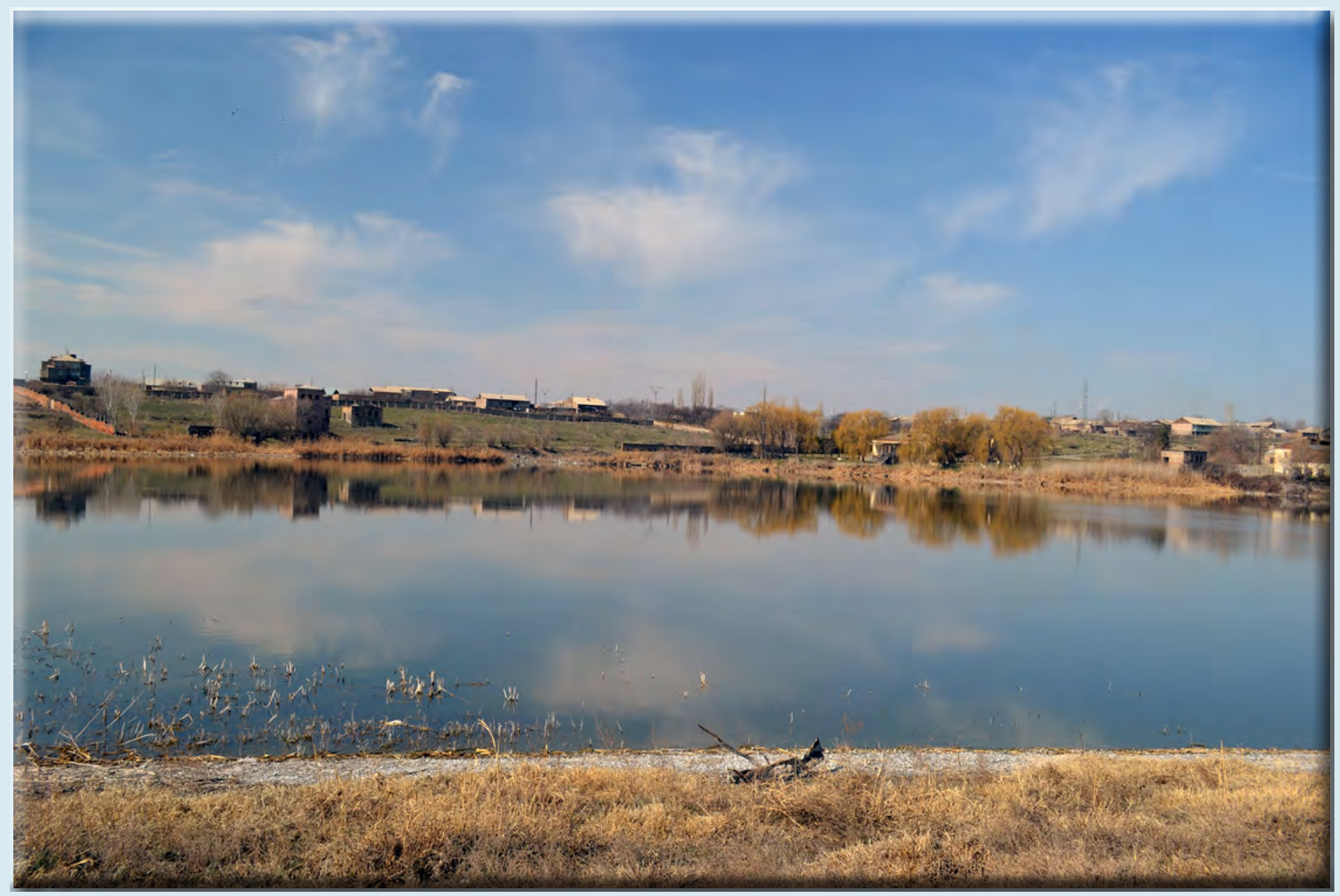

Figure 4. The water level of this groundwater fed lake in the Ararat Basin is about 8 feet (2 meters) lower today (2016) than a decade ago because of lower groundwater levels in the aquifer. The stream that once flowed from the lake is dry.

\section{Approach}

The USGS team provided in-country training to hydrology professionals in February-March 2016 in Yerevan, Armenia. Topics included groundwater modeling (fig. 5), well inventory, collection of water-level data (fig. 6), measuring well discharge, and water-quality sampling, including selected stable isotopes and cesium-137 for age-dating purposes (fig. 7). This training included classroom-style lectures in Yerevan and field training at selected sites visited in March 2016 (fig. 1) including flowing and nonflowing wells and surface-water features. Using the training provided by USGS, our Armenian partners, such as personnel from the ASPIRED program and the Hydrogeological Monitoring Center, will be collecting data on status of wells, water levels, and basic field water-quality constituents during the summer of 2016 .

The USGS will develop a hydrogeologic framework for the Ararat Basin to support the development of a groundwaterflow model. A model will permit the simulation of changes in discharge rates from wells (such as benefits of sealing abandoned wells) and changes in basin recharge rates (such as drought conditions). Characterization of the artesian aquifer will include areal extent, thickness, depth, water levels, flowing and nonflowing conditions, and recharge and discharge rates. In addition, Interferometric Synthetic Aperture Radar (InSAR) imagery will be used to determine if land subsidence has occurred or is occurring due to groundwater depletion.

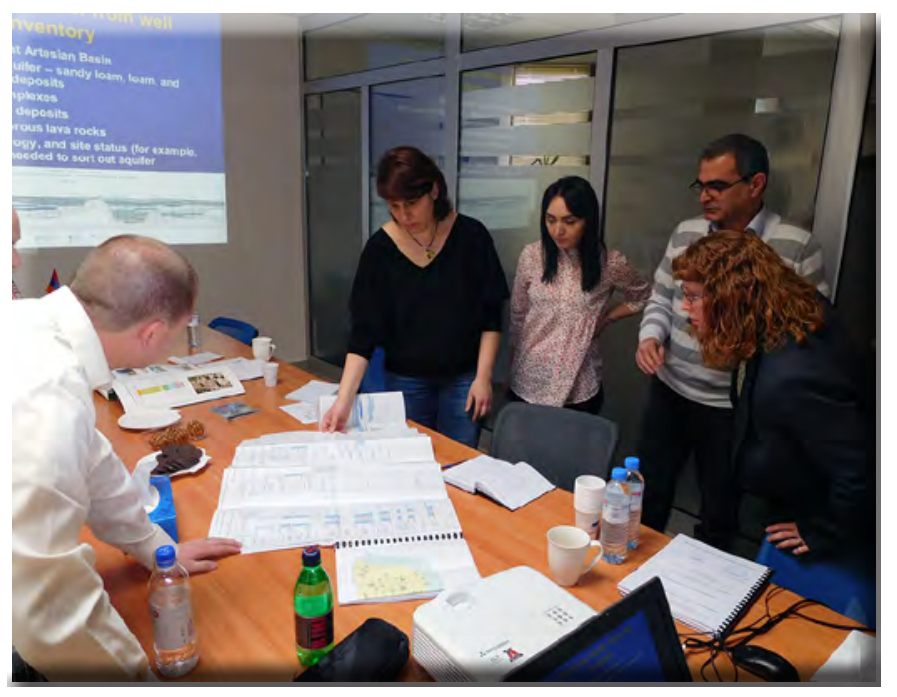

Figure 5. Groundwater modeling was discussed with our Armenian partners as a useful tool to help manage groundwater resources in the Ararat Basin. Here, the group discussed generalization of geologic units using available lithologic logs for purposes of groundwater modeling. 

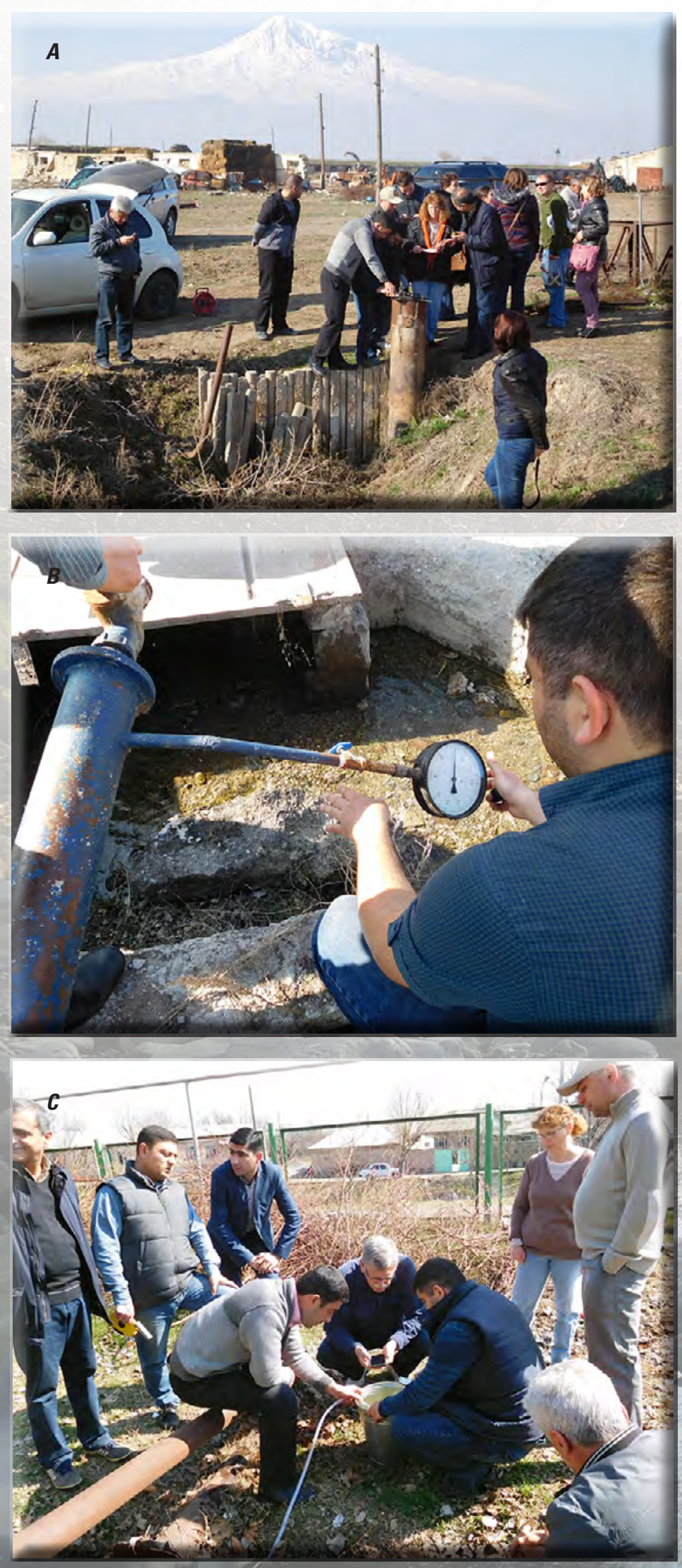

Figure 6. Field training on March 2, 2016, on the collection of hydrologic data. A, Collection of water-level data from a nonflowing well near Ararat, Armenia (Mt. Ararat is in background); B, collection of water-level data from a flowing wellnear Masis, Armenia; $C$, measurement of well discharge from a nonflowing well near Artashat, Armenia.

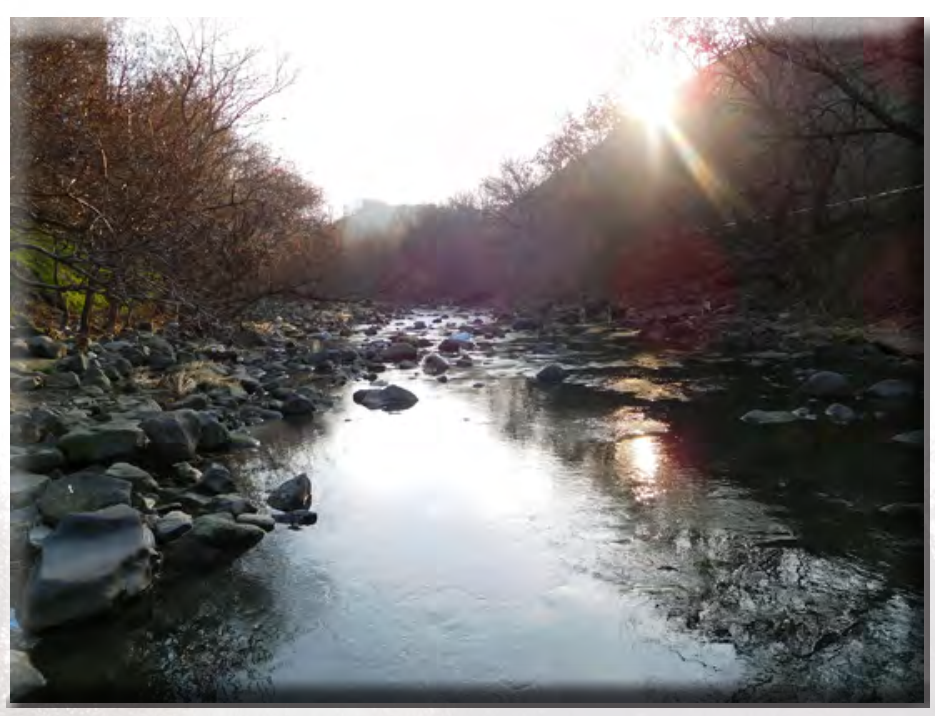

Figure 7. Hrazdan River at Yerevan, Armenia, where water samples were collected for analysis of select stable isotopes and cesium-137.

\section{References Cited}

Armenian Branch of Mendez England and Associates, 2014, Assessment study of groundwater resources of the Ararat Valley - Final report: Prepared under subcontract agreement HAYJRNAKHAGITS-23/01/13-1 for U.S. Agency for International Development, $62 \mathrm{p}$.

Nalbandyan, Marine, 2012, Management and perspectives of using of underground freshwaters from transboundary aquifers in Armenia: 12th International Multidisciplinary Scientific GeoConference SGEM, June 17-23, 2012, v. 3, p. 769-775.

Yu, Winston, Cestti, R.E., and Lee, J.Y., 2015, Directions in development - countries and regions - Toward integrated water resources management in Armenia: Washington, D.C., World Bank Group, accessed May 9, 2016, at http://dx.doi. org/10.1596/978-1-4648-0335-2.

For more information, contact:

Director, USGS South Dakota Water Science Center 1608 Mountain View Road

Rapid City, South Dakota 57702

http://sd.water.usgs.gov/ 